\title{
Capacity Development-oriented Service Delivery Structures and Programmes: Case Study of a Mineral-rich District Municipality
}

\author{
Dr. Matuku Mphahlele (Corresponding Author) \\ (University of the Witwatersrand) \\ 2 St. Davids Pl, Parktown 2050 \\ Johannesburg, South Africa \\ Dr. Horacio Lucas Zandamela \\ Honorary Research Fellow \\ School of Management, IT \& Governance \\ (University of KwaZulu-Natal)
}

Received: Dec. 26, 2021 Accepted: Jan. 28, 2022 Online published: Feb. 16, 2022

doi:10.5296/jpag.v12i1.19363ＵRL: https://doi.org/10.5296/jpag.v12i1.19363

\begin{abstract}
Bojanala Platinum District Municipality (BPDM), in the North-West Province, South Africa, is endowed with an extractive economy. The District experiences challenges of capacity development of service delivery structures and programmes. It is in this context that this paper examines how local government responses to challenges of capacity development and explores ways in which organisational structures and programmes can be used to overcome these challenges for enhanced service delivery. The theoretical framing of this study underpins capacity development as an enabler of service delivery and incorporates human capital, performance improvement and collaborative participation in the context of local government. The research employed a single case qualitative research approach with a component of descriptive statistics and a sample of 30 municipal senior managers and a social development mine manager. Key findings are that organisational learning and skills development play important roles in enhancing the capacity development of service delivery structures and programmes. It is against these findings that the study recommends the creation of supportive monitoring and evaluation systems to advance the strengthening of
\end{abstract}


functional hybrid governance structures and an organic communication model within a transparent and accountable administrative-political environment.

Keywords: local government, capacity development, service delivery, skills development, performance, collaboration

\section{Introduction}

\subsection{The Approach}

This study examines the problem of the acquisition of skills in relation to compliance with existing legislation to enhance service delivery (Bojanala Platinum District Municipality, 2016). The Bojanala Platinum District Municipality (BPDM) experiences the problem of the delivery of basic services and capacity development not meeting the desired outcome stronger capacity. Inadequate expertise and management capacity, and poorly funded weak institutions are key causes of poor service delivery in the South African local government context (Guillermo et al., 1999; Roux \& Nyamukachi, 2005). Little is known on how to overcome service delivery challenges related to the lack of skills and instability of the management teams (Bojanala Platinum District Municipality, 2016; Madibeng Local Municipality, 2015). Existing literature argues that organisations facilitate learning to narrow the skills gap through human capital development (Becker, 1993; Zula \& Chermack, 2007) and performance improvement (Swanson, 1999; Rummler \& Brache, 1988). In addition, Imperial (2005) and Ansell and Gash (2007) advocate for the use of collaborative governance in the promotion of facilitative leadership and municipal participatory governance. This study therefore examines the intricacies and nuances at the interface of human capital, performance improvement and collaborative governance theories in relation to capacity development of service delivery structures and programmes. The purpose of this study is to examine the nature of capacity development challenges in the context of service delivery, and explore how organisational structures and programmes can overcome these challenges. The study answers the primary question: What are the difficulties militating against the capacity development of service delivery structures and programmes, and how can they be overcome? The methodology employed semi-structured interviews, thick description of data and a qualitative naturalistic inquiry consistent with the recommendations of Guba (1981), Denzin and Lincoln (2011), and Merriam (2002). Data was collected in 2016 over a period of three months in the five local municipalities in the Bojanala Platinum District Municipality.

\subsubsection{Contextual Orientation of the Study}

The geographical location of the study is the Bojanala Platinum District Municipality (BPDM), North-West Province in South Africa. The District municipality is composed of five local municipalities, which are Moretele, Moses Kotane, Rustenburg, Madibeng and Kgetlengrivier in the mineral-rich 'platinum belt' of South Africa. The platinum belt experiences difficulties of (1) unstable mobile labour force, (2) political elitism, and (3) inadequate public-private collaborative partnerships in relation to capacity development of service delivery structures and programmes in the mineral endowed economy. Another unique feature and compelling motivation for the context of this study is the state brutality 


\section{Macrothink Institute ${ }^{\text {IM }}$}

experienced in the fatal shooting of 34 mine workers and four protesting members of the community in the Marikana and Mothutlung villages, Madibeng local municipality. This study, therefore, advances the social and economic issues distinctly interwoven in the enhancement of capacity development in the District.

The contextual orientation, in the main, covers the space in the legislative, socio-economic and skills development intersection.

The Constitution of the Republic of South Africa, Act 108 of 1996, underpins the essence of compliance in relation to the capacity development of human resources consistent with local government service delivery, whereas the Local Government Municipal Systems Act 32 of 2000 spells out the intentions of the municipal systems. The post-Apartheid legislative instruments seek to redress the historic marginalisation of the majority of the citizenry from mainstream economic activities. Although the local municipalities are endowed with the extractive capital, they have not succeeded in the alignment of the municipality-driven Integrated Development Plan (IDP) and the mine-driven Social and Labour Plan (SLP) to develop host communities (Department of Mineral Resources [DMR], 2015).

The focus on the socio-economic environment contextualises some historical social realities. Difficulties experienced in the BPDM are, for instance, social realities, including socio-economic inequality and youth unemployment, poor school facilities and sparsely populated local municipalities. Statistics South Africa [Stats SA] (2013) reveals that 43\% employment in the BPDM is in the mining sector; however, 39\% of the youths are unemployed. The uncontrollable influx of migrant labourers burdens the municipal fiscus and other limited resources that are needed to enhance service delivery.

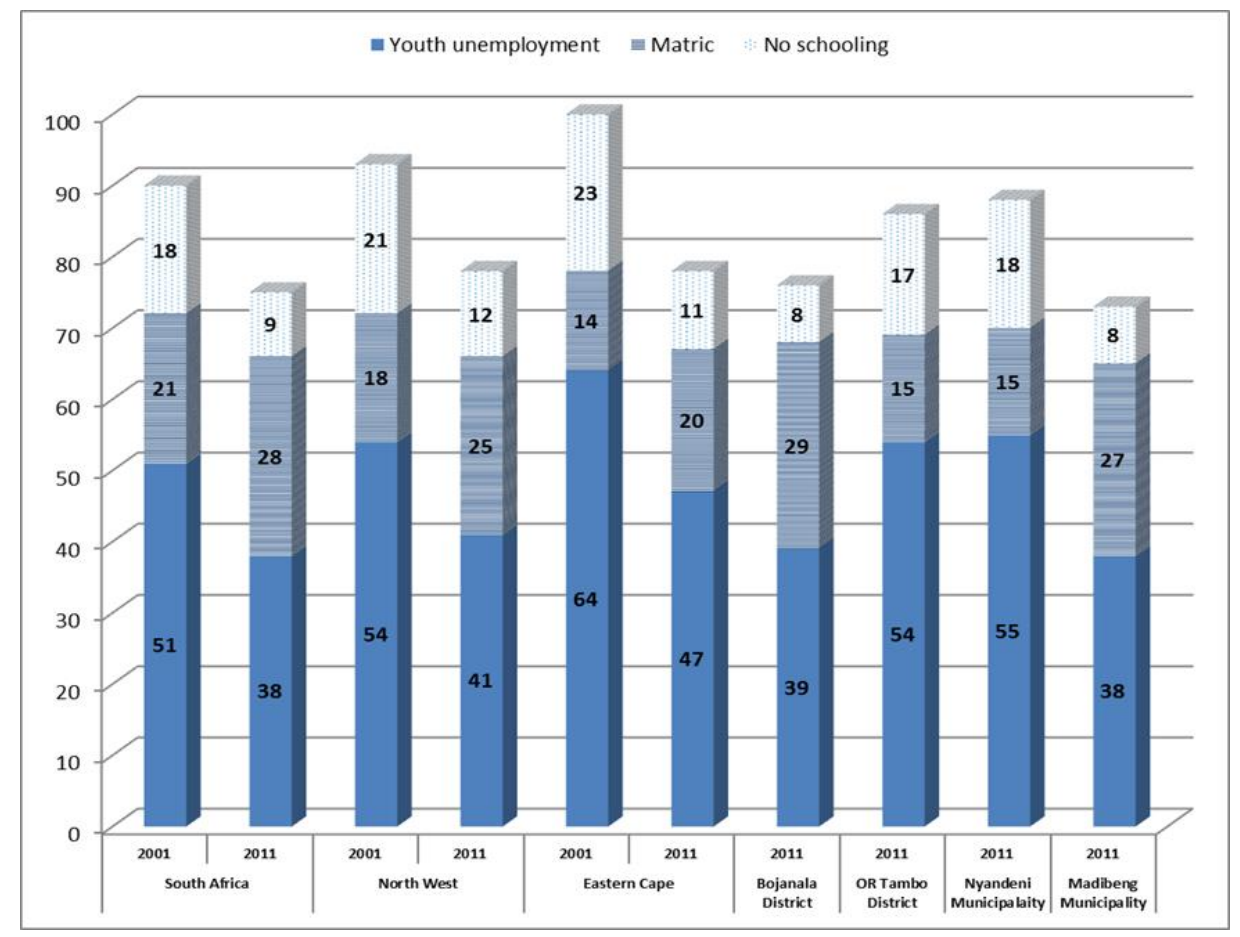

Figure 1. Bojanala and OR Tambo percentage population dynamics Source: Statistics South Africa (2013) 


\section{Mll Macrothink}

Journal of Public Administration and Governance

ISSN 2161-7104

2022, Vol. 12, No. 1

The comparison of the population dynamics (Figure 1) of the labour sending Nyandeni local municipality, in the OR Tambo District Municipality, in the Eastern Cape Province and the Madibeng host local municipality, reveals the deep-rooted social problems that the BPDM confronts. There are startling discrepancies that provoke the question, "what are the service delivery context-specific socio-economic realities in relation to inter-provincial labour migrant movements?" The highest migrant labourers in the BPDM are from the Eastern Cape. This movement weakens the economic resilience of labour sending municipalities. To cite an example, the percentage of people with no schooling in the Nyandeni municipality (18\%) is more than double that in Madibeng (8\%) and unemployment in the Nyandeni municipality is about 17\% more than the rate of youth unemployment in South Africa in 2011 (Statistics South Africa [Stats SA], 2013). The extent of poverty and unemployment in the BPDM differs among the local municipalities. Unemployment in Moretele is at 57\%, much higher than the average 39\% unemployment across all local municipalities in the District. Furthermore, the lowest increase in matriculated youth is in the rural under-resourced Kgetlengrivier Local Municipality at $6 \%$. Census in South Africa is conducted every five years, hence the most recent figures were released in 2013.

The unemployment rate in the Bojanala District could be attributed to the gap between their level of education and the employment requirements (Dubihlela \& Volschenk, 2017). Notwithstanding the remedial intervention against poverty in the form of social wage polices such as free basic education, high unemployment is more prevalent in the North-West Province (Statistics South Africa, 2017). These varied socio-economic factors including inequality advanced in the foregoing discussion underpin some alarming discrepancies in relation to the host-labour sending municipal conduit which, in this study, is referred to as the 'Madibeng-Nyandeni corridor'.

Although the study explains contextual issues in relation to capacity development, socio-economic elements associated with population sparsity could explain how a myriad of impediments impacts on service delivery. The demographic profile of the BPDM indicates that the population in the BPDM increased by about 10\% in five years (2011-2016). There are huge population density discrepancies, with Madibeng and Kgetlengrivier at 389 people $/ \mathrm{km}^{2}$ and 15 people $/ \mathrm{km}^{2}$ respectively (Stats SA, 2016). The most sparsely populated Kgetlengrivier local municipality experiences the highest poverty rate at $78 \%$ in the BPDM compared to the most populated Madibeng local municipality at 47\% (South African Institute of Race Relations, 2014). The sparsity of the population over vast areas could be a contributory factor for the high youth unemployment rate of $50 \%$ in the Moretele local municipality (Stats SA, 2013). Sparsely populated areas in rural local municipalities depend on natural resources and, to some extent, migratory labour (National Treasury, 2011). In the South African context, Africans carry the overwhelming share of poverty at $91,5 \%$ and $93,0 \%$ in 2006 and 2015 respectively, and this is consistent with the belief that the educational level of the citizens is closely related to poverty (Statistics South Africa, 2017). Accordingly, to complete the contextual orientation, this study hones in on skills development programmes in the post-school environment.

In his first state of the nation address in 1994, the late former President Mandela 
demonstrated a political will to empower the workforce. The public and private sectors were encouraged to regard labour as a resource and were supposed to be empowered through skills training (South African Government, 1994). In the South African context, legislation addressed the historic poor education and exclusion of Africans in the workplace skills training programmes. The Skills Development Act 98 of 1998 aimed to improve the delivery of services, education and training, and the quality of life and labour mobility of workers.

Table 1. Sector-specific occupational skills in the mineral and mining sector

\begin{tabular}{|c|c|c|c|c|c|c|c|c|c|}
\hline \multirow{2}{*}{$\begin{array}{c}\text { Occupational } \\
\text { Group }\end{array}$} & \multicolumn{2}{|c|}{ African } & \multicolumn{2}{|c|}{ Coloured } & \multicolumn{2}{|c|}{ Indian } & \multicolumn{2}{|c|}{ White } & \multirow{2}{*}{$\begin{array}{l}\text { Grand } \\
\text { Total }\end{array}$} \\
\hline & Number & $\%$ & Number & $\%$ & Number & $\%$ & Number & $\%$ & \\
\hline Managers & 5031 & $1 \%$ & 502 & $4 \%$ & 487 & $18 \%$ & 8656 & $12 \%$ & 14676 \\
\hline Professionals & 13604 & $3 \%$ & 1103 & $8 \%$ & 781 & $28 \%$ & 10891 & $16 \%$ & 26379 \\
\hline Technicians & 38698 & $8 \%$ & 1944 & $15 \%$ & 529 & $19 \%$ & 19693 & $28 \%$ & 60864 \\
\hline $\begin{array}{l}\text { Clerical } \\
\text { support } \\
\text { workers }\end{array}$ & 14865 & $3 \%$ & 1331 & $10 \%$ & 419 & $15 \%$ & 6537 & $9 \%$ & 23152 \\
\hline $\begin{array}{l}\text { Service and } \\
\text { sales workers }\end{array}$ & 5382 & $1 \%$ & 207 & $2 \%$ & 24 & $1 \%$ & 709 & $1 \%$ & 6322 \\
\hline $\begin{array}{l}\text { Trades } \\
\text { Workers }\end{array}$ & 20066 & $4 \%$ & 1810 & $14 \%$ & 258 & $9 \%$ & 14852 & $21 \%$ & 36986 \\
\hline $\begin{array}{l}\text { Plant and } \\
\text { machine } \\
\text { operators }\end{array}$ & 235107 & $49 \%$ & 4260 & $32 \%$ & 194 & $7 \%$ & 4775 & $7 \%$ & 244336 \\
\hline $\begin{array}{l}\text { Elementary } \\
\text { occupations }\end{array}$ & 145082 & $30 \%$ & 2202 & $16 \%$ & 74 & $3 \%$ & 3256 & $5 \%$ & 150614 \\
\hline Grand Total & $\begin{array}{l}477835 \\
(84.8 \%)\end{array}$ & $100 \%$ & $\begin{array}{l}13359 \\
(2.4 \%)\end{array}$ & $100 \%$ & $\begin{array}{c}2766 \\
(0.5 \%)\end{array}$ & $100 \%$ & $\begin{array}{c}69369 \\
(12.3 \%)\end{array}$ & $100 \%$ & 563329 \\
\hline
\end{tabular}

Source: Mining Qualifications Authority (2014).

Understanding of the historic context of the mining sector in South Africa and the application of the relevant responsive legislative instruments explains the justification to address social and economic inequality among the historically disadvantaged South Africans.

It is against this backdrop of socio-economic inequality in the mineral and mining sector that the study examined the intersection of workplace training and racial inequality at the level of organisational decision-makers. The Employment Equity Act, No 55 of 1998, redresses unfair discrimination at workplaces and promotes equitable representation at all occupational categories. Notwithstanding the promulgation of the Skills Development and Employment Equity Acts, unfair workplace racial discrimination in the mineral and mining sector manifests in a bias against Africans at the level of decision-makers as Table 1 illustrates. The unskilled elementary occupational group is dominated by Africans at 145082 (96\%) out of a total of 150614 employees. This unfair discrimination, according to the Employment Equity 
Act, No 55 of 1998, puts Africans at a disadvantage when it comes to policy decision-making, monitoring and implementation of the Employment Equity Plan. There is a huge anomaly when it comes to senior management positions with $34.3 \%$ of Africans occupying such positions as compared to $59.0 \%$ of Whites, and females constitute only $14.4 \%$ of the workforce (Mining Qualifications Authority [MQA], 2014). The Engineering Council of South Africa [ECSA] (2014) asserts that most engineers are White (65.4\%). Notably, out of 100 Indians, 18 are in management, compared to only one African at the same level. These profound discrepancies happen despite Africans being in the majority at 477835 (84.8\%) (MQA, 2014). This is a gloomy workplace picture consistent with the premise of the National Development Plan that South Africa is a divided country (National Planning Commission, 2011). According to the regulations of Employment Equity Act, top managers have the advantage of a long-term job cycle whereas the unskilled at elementary occupations have short job cycles. The Mineral and Petroleum Resources Development Act 28 of 2002 proclaims that mining companies have to establish collaborative partnerships with the host and labour sending municipalities to enhance service delivery. However, and to the contrary, only $36 \%$ of mining right holders have met their set target on mine community development nationally (Department of Mineral Resources, 2015). An understanding of the legislative space, including skills development and socio-economic issues, deepens our knowledge of underlying factors that impact on local government capacity development.

Unemployment and geographical settings are elements not only distinctly peculiar to the rurality of local municipalities but also hostile to capacity development. An examination of how these elements interact in the ecology of power imbalance in the space of traditional authorities, municipal councils and multi-national companies advances our understanding of how to overcome service delivery impediments. Subsequently, aspects of power imbalance prompt the question, how can socio-economic challenges in both the host and labour sending local municipalities, referred to as the 'Madibeng-Nyandeni corridor', be overcome? The nature of challenges described in the foregoing sections encourages us to examine enablers and disablers in the area of capacity development initiatives.

\subsubsection{Organisational Change Within a Learning and Responsive Socio-Political Environment}

This study examined employee skills development, municipal performance and collaborative governance measures in relation to the capacity development of service delivery structures and programmes adopted from Mphahlele and Zandamela (2021). Existing literature reveals that aspects of administrative collaboration, remittance system, state violence and a volatile labour setting are intrinsically intertwined in the context of municipal service delivery. These difficulties prompt the primary question: What are the difficulties militating against the capacity development of service delivery structures and programmes, and how can they be overcome? Capacity development involves local communities, organisations, leaders and coalitions within the socio-political milieu. Otto et al. (2009) define capacity development as a "locally driven process of learning by leaders, coalitions and other agents of change that bring about changes, in socio-political policy-related and organisational factors to enhance local ownership, effectiveness and efficiency of efforts to achieve a developmental goal" (p.9). The Organisation for Economic Co-operation and Development (2008) adds that 
"capacity development is a process whereby people, organisations and society unleash, strengthen, adapt and maintain capacity over time" (p.244). In the South African local government context, service delivery is the distribution of basic resources and sustainable services by the municipality to ensure an acceptable and reasonable quality of life to the satisfaction of communities (Akinboade et al., 2014; Fox \& Meyer, 1995; Ndebele \& Lavhelani, 2017; Nealer, 2014). Capacity development-oriented service delivery in the context of this study, therefore, is the process of organisational change within a responsive socio-political environment. Human resource development is an enabling instrument that advances effective capacity development across all sectors (Harbison \& Myers, 1964). This space therefore explains how elements peculiar to capacity development enhance service delivery in the administrative and political environments premised on human resource development initiatives.

An examination of intricacies and nuances at the confluence of capacity development and human resource development issues heightens our understanding not only of structures and programmes for the enhancement of service delivery but also how they can be improved. The roles of senior managers under the leadership of the municipal manager complement the fiduciary roles of political office bearers as agents of change in meeting the desired outcomes of both communities and the private sector. Thus, developmental programmes at the intersection of the administrative and political environments extend into the social and economic milieu. Administrative collaboration could be an enabler of organisational performance and inter-municipal capacity development, as existing literature suggests. Administrative collaboration in the form of inter-municipal co-operation preserves local autonomy without impacting on service delivery (Allers \& de Greef, 2018; Soukopová \& Vaceková, 2018). Notably, and to the contrary, Blaeschke and Haug (2018) assert that inter-municipal co-operation may complicate the co-ordination of stakeholder interests due to the spread of accountability over a wider spectrum. Concerning public-private partnerships, the private sector promotes the optimisation of the capacity of management and enhancement of service delivery (Germà \& Gradus, 2018; Shava \& Maramura, 2016). At an individual level, functional municipal provisioning of basic services is affected by both the pursuit of public interests (Huang \& Feeney, 2016) and the pursuit of self-interest (Fairhurst, 2007). Political elitism at the administrative-political juncture leads to the pursuit of self-interests that typically weaken local government institutions (Dzansi et al., 2016; Hodder, 2009; Ngwenya \& Botha, 2014).

An explanation of the effective interactions of distinct elements at the interface of the social and economic environments prompts the question; what are the supportive roles of mining companies in public-private partnership relations and how do local municipalities lead in the maximisation of the use of resources for service delivery? Following the discussion on the nexus between the administrative and political settings, this study delves into such socio-economic elements as are characterised by the unsustainable remittance system, state violence and a volatile labour setting. The flow of money from the host local municipalities in the form of remittance in the mineral and mining sector is to some extent distinctly and peculiarly consistent with the phenomenon of migratory cheap labour of male Africans 
(Wolpe, 1972). The phenomenon of cheap labour is also consistent with the concept of the 'rural-urban' nexus referred to as translocal livelihood (Lohnert \& Steinbrink, 2005). In addition, Steinbrink (2010) attributes the flow of money, cultural identity and livelihoods to complexities of the rural-urban imbalance or the persistent mobile community settings. In the Southern African context, the historic traditional 'walk to the mine' of African males gives rise to remittance arrangement or systems to support households back home (Adaawen \& Owusu, 2013; Amoako \& Apusigah, 2013; Lohnert \& Steinbrink, 2005; Mayer \& Mayer, 1971; Sana \& Massey, 2005; Stark, 1991; Stark \& Lucas, 1988; Steinbrink, 2010). However, there are shortcomings to the system. To cite an example, Ghanaian studies argue that the remittance arrangement by its nature may not always improve hard-earned income of mine workers and aggravates issues with fathers back home squandering the hard-earned monies sent by their sons (Abdul-Korah, 2011; Kwankye; 2012; Serbeh et al., 2015).

State violence against the citizenry in the extractive economy is one of the causes of socio-political instability, as existing literature suggests. In the context of the South African historic marginalisation of Africans from the mainstream economic system, the discovery of minerals in Kimberly in the late 1860s and the supporting structure of racial segregation resulted in the violent seizure and looting of land and property from African chiefs/magosi in President Paul Kruger's era (Turrel, 1986). Post-Apartheid era South Africa also witnessed the fatal shooting of 34 mineworkers in the Madibeng local municipality, at Marikana village in 2012 (Sorensen, 2012; Satgar, 2012). Similarly, again in the Madibeng local municipality, Mothotlung village, four protestors were fatally shot in 2014 by the state police while demonstrating against lack of service delivery (Govender, 2014). The argument in Latin American studies by Lust (2014), and Busse and Gröning (2013) that the aim of state brutality is to 'kill' and render labour movements and activism ineffective is consistent with the South African experience in the Marikana tragedy.

Lastly, another dimension in the creation of organisational change in the context of capacity development-oriented service delivery structures and programmes is the perceived expansion of the phenomenon of cheap labour into the volatile mining related labour setting. The violation of the rights of workers and their families in the mining sector is not limited to the South African experience. The mining boom in rural Australia adversely affected the wellbeing of mine workers, resulting in family breakdowns, violence, and suicide (Carrington et al., 2011; Carrington \& Hogg, 2011). The Australian fly-in, fly-out (FIFO) or drive-in, drive-out (DIDO) labour setting affects the psychological wellbeing of mine workers and creates family dislocations (Biggs et al., 2015; Houghton, 1993; Keown, 2005). Similar findings in Peru argue that multinational mining companies exacerbate the rupture of family structures and poor relationships with the local government. To the contrary, favourable institutional change is likely to emerge from conflict and negotiation in the extractive sector (Bebbington et al., 2013). Similarly, youth-led social activism and protests against multinational mining companies may lead to citizen engagement, whereupon employment opportunities expand (Wilson, 2013).

In summary, the lack of political accountability cannot be precluded from the myriad of nuances distinctly linked to social ills and brutality of the state and multi-national mining 
companies. The administrative-political nexus is non-responsive to adequate service delivery. The phenomenon of cheap labour is consistent with the concept of the 'rural-urban' nexus. Aspects associated with cheap labour and the rurality of the municipal settings creep into the socio-economic milieu to advance power imbalances in the form of an uneconomic remittance system and family fragmentations. Thus, 'fiscus flight' premised on the mobile migrant labour setting negatively impacts on the collection of taxes and municipal rates. Any likelihood of economic spin-offs from the creation of jobs or 'resource blessing' is stifled in the absence of administrative-political collaboration. Little is known on how capacity development-oriented difficulties related to service delivery structures and programmes can be overcome at a municipal level.

\subsection{Framing of the Research Study}

Framing of the study models relationships and explication of theories that influence the research.

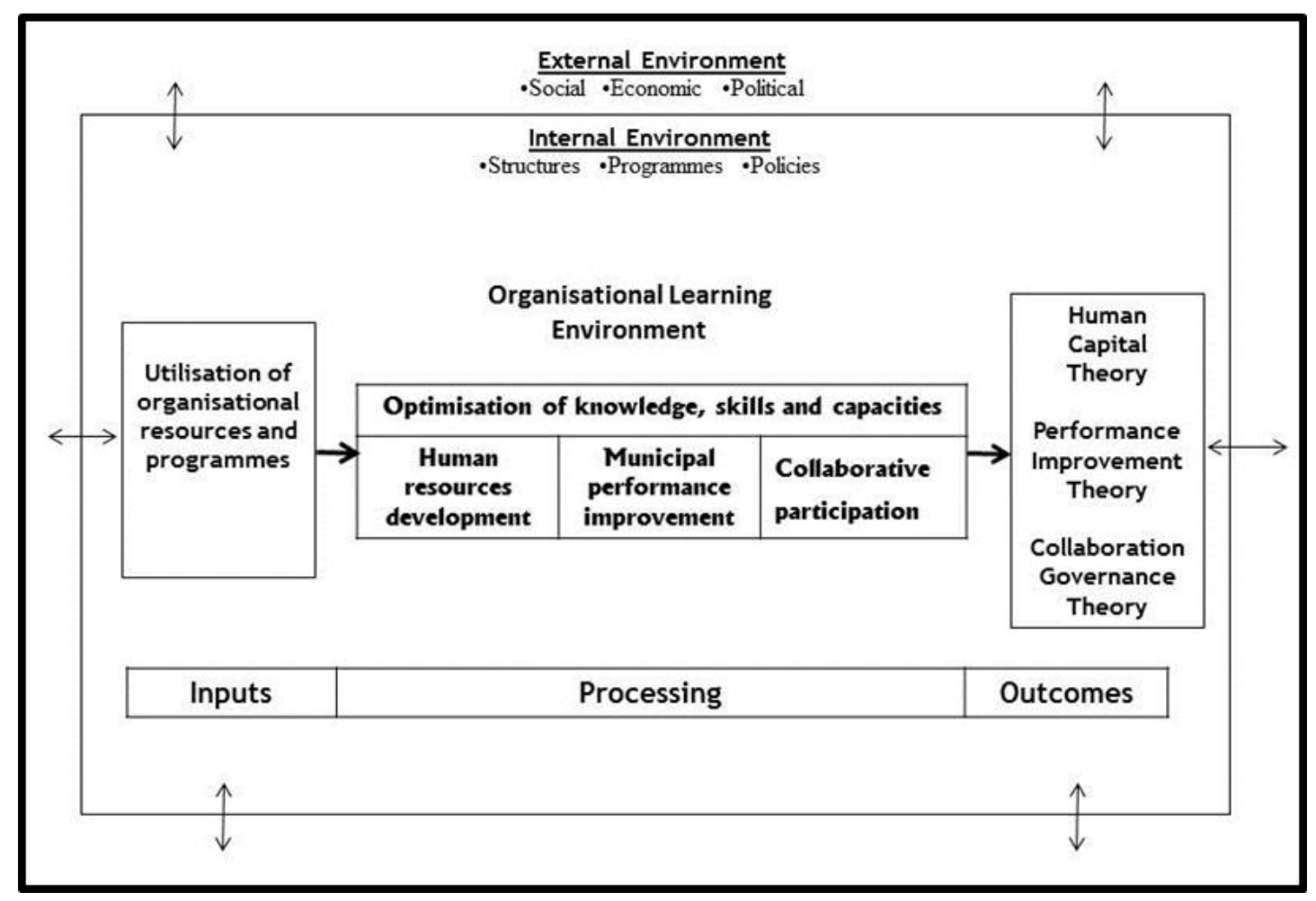

Figure 2. Representation of the Theoretical Framework

Source: Mphahlele (2021).

Human resource planning in the administrative realm determines the extent of organisational skills deficit or skills surplus. Premised on the extent of skills supply and demand, the utilisation of organisational resources and programmes serves as inputs in the organisational learning process, as illustrated in Figure 2. The extent of the integration of elements within the internal environment heightens prospects for the creation of a learning environment. Thus, organisational learning is not only a key enabler in the narrowing of the capacity gap, but also 
a vehicle for the optimisation of knowledge and skills capacities. The optimisation of knowledge and skills capacities occurs through the distinct elements peculiar to human resource development, performance improvement and collaborative participation. This model is a revised version of the theoretical framework originally advanced by Mphahlele and Zandamela (2021). The emergent human capital theory fundamentally initiates activities to address the skills gap that results from an imbalance of skills demand and skills supply at the entry point to municipal performance and participation. Moreover, the performance improvement theory cuts across both the human capital and collaborative governance theories. Following the optimisation of knowledge, skills and capacities, outcomes from processing the internal environment policies, structures and programmes yield the threesome capacity development-oriented theories discussed hereafter.

Human capital theory advances education and training programmes, employee turnover and employee retention strategy as well as financial benefits acquired from investment in human capital (Becker, 1993; Harbison \& Myer, 1964; Zula \& Chermack, 2007). To the contrary, skilled labour is perceived as a commodity to maximise capitalist profit and legitimises economic inequality (Bowles \& Gintis, 1975). Performance improvement theory focuses on human performance linked to economic investment and provisioning of rewards to enhance productivity inclusive of consequence management (Denison; 1967; Gilbert, 1978; Rummler \& Brache, 1988; Swanson, 1999). A dissimilar argument is that performance incentives reward and encourage exploitation at workplace (Korten, 1995). Lastly, the collaborative participatory governance theory promotes democratic participation inclusive of the vulnerable (Ansell \& Gash, 2007; Edelenbos, 2005; Imperial, 2005; March \& Olsen, 1989; Waheduzzaman \& Mphande, 2012). To the contrary, preference systems in the reward of performance reinforce inequality, and deepen uncertainty, and manifest into the 'new tyranny' through which the manipulative elites limit opportunities for growth at the workplace (Cooke \& Kothari, 2001; Mansuri \& Rao, 2004; Platteau, 2008; Somville, 2006; Tembo, 2003; Nygren, 2005).

The study assumes that enhancing capacity development-oriented service delivery structures and programmes would address difficulties associated with employee skills development, implementation of the legislative mandates, and collaborative partnerships with local multi-national mining companies. An adaptation of the theoretical perspectives forms the conceptual framework that guided the study. The conceptual framework assisted in examining key concepts (Badenhorst, 2007). 


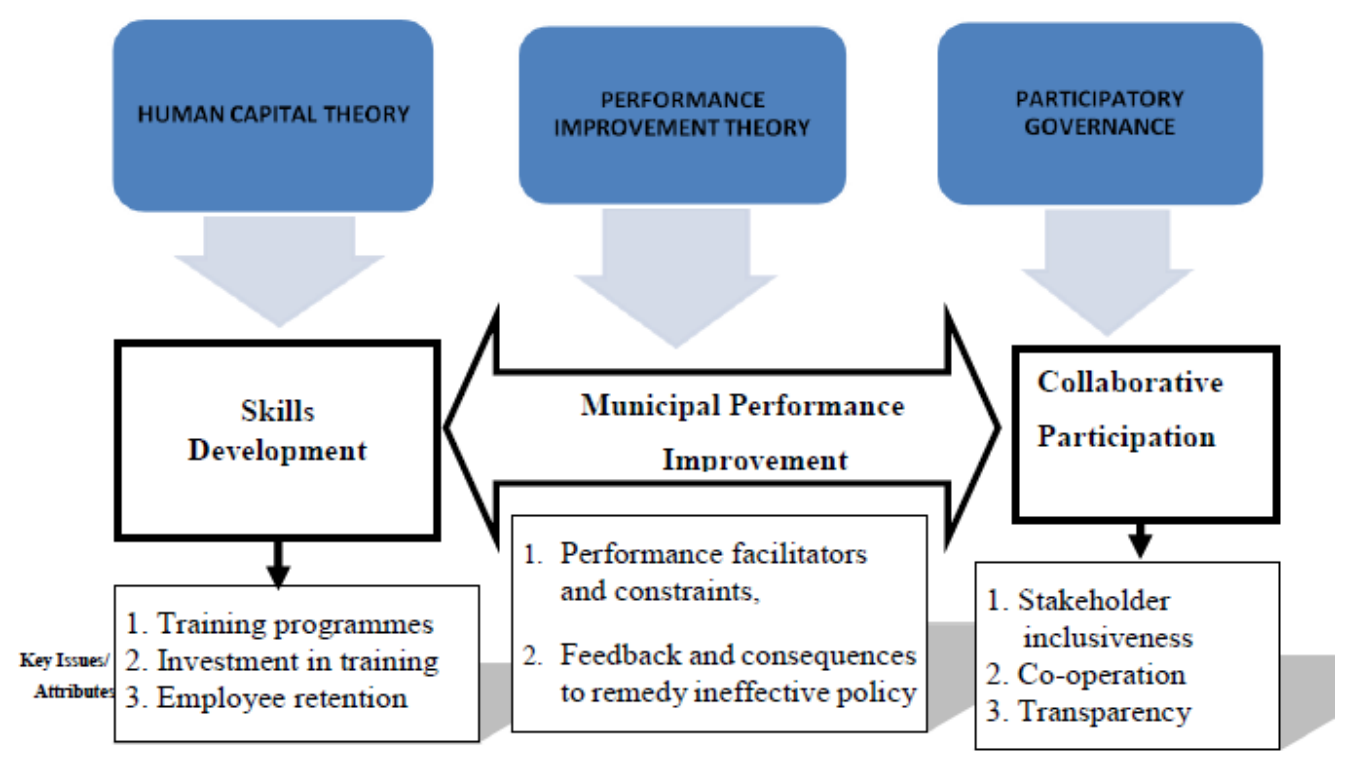

Figure 3. Capacity development Conceptual Framework

Source: Mphahlele (2021)

In line with the argument in Rocco and Plakhotnik (2009), the conceptual framework in Figure 3, that is, the revised version of Mphahlele and Zandamela (2021), discusses the concepts that situate the study, and illustrates them with a figure. The conceptual framework assumes that capacity development is an enabler of service delivery, and underpins organisational skills development, municipal performance, and collaborative participation. The interdependence among the concepts is framed on the grounds that skills development is the leading enabler. Thus, skills development stimulates the optimisation of municipal performance and collaborative participation. The skills development concept advances the assertion that organisational investment in training programmes facilitates the implementation of capacity development. The study further probes the extent to which performance management systems facilitate or constrain feedback and the management of consequences.

The foregoing discussions delve into the framing of the study and underpin elements peculiar to an understanding of capacity development in the context of a South African local government tier of governance. Thus, this provokes the question of what methodology was employed in the examination and understanding of disablers of local government capacity development and how they can be overcome.

\section{Method}

The study employed in-depth face-to-face interviews of a purposive sample of 30 municipal senior managers as well as a manager from the local mining company. This sampling is consistent with their knowledge and roles in relation to capacity development in their respective departments. The rich knowledge of the respondents provided a deep understanding in the examination and interpretation of findings. The philosophical underpinning of this study was therefore an interpretive paradigm. The paradigm by its nature 
served as a vehicle and enabler in the interpretation of managers' subjective understandings of multiple beliefs or experiences on municipal capacity development. In addition, the study employed the questionnaire as a complementary descriptive statistics component consistent with the argument in Morse (1991).

The rationale for using sequential triangulation with the qualitative approach followed by the descriptive statistics component allowed for a broader perspective of viewpoints (Field \& Morse, 1985). The questionnaire was employed consistent with the recommendations of Neuman (2011) to describe issues and explain reasons for the occurrence of the phenomenon of capacity development examined in the interviews. Emergent themes developed after the qualitative analysis of responses from in-depth interviews in group A were employed to construct close-ended questionnaires for group B with structured questions. Group B respondents were asked to indicate 'strongly disagree', 'disagree', 'agree' or 'strongly agree' consistent with the Likert Scale. The data collected was suggestive of the non-numerical 'intensity' of their attitude on an ordinal scale consistent with the use of descriptive statistics (Kaur et al., 2018). A total of 56 questionnaires were distributed, 55 were returned and three spoilt. The study effectively had 52 questionnaires to analyse using coding followed by descriptive statistics. Microsoft Excel was used to calculate only the average percentage frequency and sum of responses to the 'intensity of belief', that is, 'Agree', 'Disagree', 'Strongly Agree', or 'Strongly Disagree'. The descriptive statistics format employs categorical variables also known as qualitative to make the information more easily interpretable (Kaur et al., 2018). To the contrary, inferential statistics uses continuous data (for quantitative variables) and histograms to interpret data (Kaur et al., 2018). The study pooled together generated themes from subjective interview perspectives and objective descriptive information derived from questionnaires to enhance the trustworthiness of the study consistent with Guba's (1981) recommendations. The following section delves into a discussion of the findings generated from interviews, questionnaires and documentary analysis.

\section{Results and Discussions}

\subsection{Data Presentation}

Data presentation, in this study, underscores perspectives, including in-depth interviews, that advance key impediments, that is, budget constraints, political interference and municipal grading. Respondent 09 (personal communication, June 30, 2016) suggested that rural local municipalities are more at a disadvantage in relation to budget allocation due to the municipal grading system. The grading system impedes the collection of revenue and provision of public service, subsequently instigating community protests (Respondent 17, personal communication, July 12, 2016; Respondents 11, 12 and 15, personal communication, July 06, 2016). In addition to budgetary constraints, political interference creates a "poisonous environment" and high staff turnover (Respondent 09, personal communication, June 15, 2016). To cite an example, some councillors would hurl insults and instructions like, "listen here, I am the boss and I instruct you to appoint so and so" (Respondent 10, personal communication, July 11, 2016). Despite the perceived positive contribution of corporate 
social responsibility (CSR) programmes, mining companies are non-committed to partnerships with municipalities (Respondent 15, personal communication, July 06, 2016). However, and to the contrary, the mining social manager asserted that during elections, councillors use the projects of mining companies for electioneering (Respondent 31, personal communication, 22 June 2016). The general worldview of middle managers is that employee performance assessments are disjointed and limited to senior managers. Furthermore, they feel deprived of knowledge in relation to municipal Integrated Development Plan (IDP) and Local Economic Development (LED) programmes. These perspectives were corroborated in the interviews. Political elites are perceived to be hoarding information and stifling knowledge dissemination across their portfolios and respective departments.

The predominant worldview among the junior-middle management in relation to skills development was that the workplace is supportive and encourages autonomy. They also found on-the-job training through the workplace skills plans and formal education support an attractive incentive. These incentives encourage employees to choose local government as an employer of choice. Although the Councils provide skills training opportunities, individual performance is not rewarded. Senior managers do not take heed of the proposals or recommendations to enhance performance management systems (PMS). Thus, the junior management level of the Performance Management Systems is largely a deterrent in attempts to maximise the capacity development of service delivery structures and programmes. Notably, the junior management felt more could be done in relation to participation in the mayoral and IDP fora as they have limited knowledge of some of the critical developmental programmes linked to their departments. To cite an example, they could be involved in the administrative allocation of infrastructure and resource inputs but do not get feedback on the actual building of clinics, mining SLP projects or completion of local sewage systems. Municipal budget allocation is not consistent with the level of poverty and deficiency of skilled labour.

Madibeng and Rustenburg local municipalities received the biggest share of the cake of R1.3b and R3b respectively in the 2012/13 to 2014/15 financial years (Local Government Handbook, 2016). Furthermore, notwithstanding the rurality of the under-resourced Kgetlengrivier, the municipality underspent R41.6m. Astonishingly, the District spent R141m on only 381 employees. On the other hand, Moses Kotane, with double the employees, spent R7m less than the District on employees (Local Government Handbook, 2016). Audit opinions in the 2016-2017 financial year reveal that only the Kgetlengrivier local municipality experienced Unqualified Audit Opinion with Findings, that is, an improved financial performance. The Auditor's Report (2018) finds shortcomings in relation to leadership, financial and performance management. The Report further also observes a lack of consequence management and failure of the District to finalise audits in the financial year 2014-2015. Despite the responsibility to lead in the coordination, facilitation and support of local municipalities, the District is found wanting with a Disclaimer Audit opinion with Findings in both 2015-2016 and 2016-2017 financial years and incurred unauthorised, fruitless and wasteful expenditures. An analysis of the findings provides vivid understanding of service delivery disablers and how to overcome them. 


\subsection{Analysis and discussion of the main findings}

Analysis of the findings generate three themes, which are, 1) Administrative fracture; 2) Political elitism; and 3) Poor socio-economic collaboration. This section hones in on how organisational relations and socio-political resilience could be strengthened against the background of disjointed structures and programmes, and poor public-private partnerships. The scarcity of political will and prevalence of political elitism weaken organisational socio-political resilience, respondents suggested. Strengthening administrative collaboration at the strategic level alleviates the intensity of volatility of the socio-political milieu. The question of how municipalities can utilise their capacity development resources is inseparable from how local mining companies contribute to capacity development in enhancing service delivery.

Typical of the nature of the extractive economy people tend to follow mining activities, and local government tend to follow people to provide services. However, due to the 'rentier effect', social responsibility programmes offer false hopes that disempower and undermine the communities. Proponents of 'resource blessing' like Labonne (2002) contend that "mining broadly contributes to poverty reduction" (p.69). To the contrary, Pegg (2006), a proponent of the 'resource curse', argues that mining activities are likely to exacerbate poverty. The argument is corroborated by the assertion that multi-national mining companies are not committed and CSR programmes are poorly designed (Conde \& Le Billon, 2017; Osei-Kojo $\&$ Andrews, 2020; Muswaka, 2014). The thematic orientation of these findings prompted the study to examine knowledge management, mentoring and change management models in the context of the research problem. It is against the complex administrative and socio-political settings that the Total Quality Management model by Deming (1982) inspired the examination of the challenges to change aspects inherent in the comfort zone (Lewin, 1947). In other words, the thematic perspectives underpin the need to shift from the comfort zone and overcome the deterrents to organisational change consistent with Kotter (1996).

Table 2. Synopsis of the capacity development model

\begin{tabular}{|c|c|c|c|c|}
\hline \multirow[b]{2}{*}{ Researchers } & \multirow[b]{2}{*}{$\begin{array}{l}\text { Operational } \\
\text { models }\end{array}$} & \multicolumn{3}{|c|}{ Capacity development phases } \\
\hline & & $\begin{array}{c}\text { Capacity building } \\
\text { plan }\end{array}$ & $\begin{array}{c}\text { Capacity } \\
\text { implementation }\end{array}$ & Capacity review \\
\hline $\begin{array}{l}\text { Gordon } \\
(2000)\end{array}$ & Mentoring & $\begin{array}{l}\text { Recognition and } \\
\text { development }\end{array}$ & $\begin{array}{l}\text { The emerging } \\
\text { independence }\end{array}$ & Letting go. \\
\hline $\begin{array}{l}\text { McAdam } \\
\text { and } \\
\text { McCreedy } \\
(1999) \text {. }\end{array}$ & $\begin{array}{l}\text { Knowledge } \\
\text { management }\end{array}$ & Knowledge creation & Knowledge sharing & Knowledge use \\
\hline $\begin{array}{l}\text { Kotter } \\
(1996)\end{array}$ & $\begin{array}{l}\text { Eight steps } \\
\text { to change }\end{array}$ & $\begin{array}{l}\text { 1. Create sense of } \\
\text { urgency. } \\
\text { 2. Build guiding } \\
\text { coalition. } \\
\text { 3. Form strategic } \\
\text { vision and } \\
\text { initiatives. } \\
\text { 4. Enlist volunteer } \\
\text { army. }\end{array}$ & $\begin{array}{l}\text { 5. Enable action by } \\
\text { removing barriers. } \\
6 \text {. Generate short } \\
\text { term wins. } \\
\text { 7. Sustain } \\
\text { acceleration. }\end{array}$ & 8. Institute change. \\
\hline
\end{tabular}




\begin{tabular}{|c|c|c|c|c|}
\hline $\begin{array}{l}\text { Deming } \\
(1982)\end{array}$ & $\begin{array}{l}\text { Total } \\
\text { Quality } \\
\text { Management }\end{array}$ & $\begin{array}{l}\text { 1. Create constancy } \\
\text { of purpose for } \\
\text { improving products } \\
\text { and services. } \\
\text { 2. Institute } \\
\text { on-the-job training. } \\
\text { 3. Drive out fear. } \\
\text { 4. Break down } \\
\text { barriers between } \\
\text { staff areas. }\end{array}$ & $\begin{array}{l}\text { 5. Institute } \\
\text { educational and } \\
\text { self-improvement } \\
\text { programmes for all. } \\
6 \text {. Everybody in the } \\
\text { company to work to } \\
\text { accomplish } \\
\text { transformation. } \\
\text { 7. Eliminate slogans } \\
\text { and targets for the } \\
\text { workforce. }\end{array}$ & $\begin{array}{l}8 \text { Adopt the new } \\
\text { philosophy. } \\
\text { 9. Constantly improve } \\
\text { planning and service } \\
\text { processes. } \\
\text { 10. Adopt and institute } \\
\text { leadership. } \\
\text { 11. Remove barriers } \\
\text { that rob people of } \\
\text { pride in workmanship. }\end{array}$ \\
\hline $\begin{array}{l}\text { Lewin } \\
\text { (1947) }\end{array}$ & $\begin{array}{l}\text { Change } \\
\text { model }\end{array}$ & Unfreeze & Change & Refreeze \\
\hline
\end{tabular}

Source: Adapted from Gordon (2000), Kotter (1996), Deming (1982), Lewin (1947), McAdam and McCreedy (1999) and Mphahlele (2021)

The impediments to service delivery cannot be resolved with a single approach. As such, a multitude of service delivery impediments were analysed and corroborated against the key components of the five functionary distinct models. Table 2 illustrates the synopsis of phases of the capacity development model generated from components of the respective models, which are, Mentoring (Gordon, 2000), Knowledge Management (Kickert, 2014; McAdam \& McCreedy, 1999; Van der Voet et al., 2016), Eight Steps of Change (Kotter, 1996), Total Quality Management (Deming, 1982) and Change Management (Lewin, 1947). A synopsis of the reviewed models captures the framework adopted in and adapted for this study for capacity development premised on the strengths of the findings. The three phases emergent from the foregoing discussions on the inhibitors of the capacity development of service delivery structures and programmes include a capacity building plan, capacity implementation, and capacity review as explained below.

The capacity building plan underscores the 'unfreeze' phase of change. At this phase, management endeavours to create a sense of urgency by building a guiding coalition that encourages the mentoring of protégés and sustains their shift from the comfort zone. To cite an example, at this phase, a purposeful political will is significant in the equitable recognition of divergent opinions and beliefs in administrative and political environments.

Capacity implementation is, in the main, a non-linear pattern in the middle ground space. It is informed by the strengths and weaknesses in the previous capacity building phase. This phase also informs how the next capacity review phase is achievable. Accordingly, it is a typical 'change' phase, an enabler of the transformation of the organisation with sustainable service delivery goals achievable through relevant workplace skills development programmes. The phase endeavours for the removal of resistance and maximisation of strengths of protégés. The motivation for transformation and transparent knowledge sharing, at this juncture, is for instance, against the background of challenges of knowledge hoarding in relation to budget allocations, roles of political elites and inadequate public-private stakeholder engagements.

Lastly, capacity review as a 'refreeze' stage is informed by the strengths and weaknesses in the preceding 'change' phase. At this phase, transformative leadership institutionalises a new organisational culture or trajectory that endeavours to maximise organisational resilience and 
administrative collaboration. In the context of service delivery in the BPDM, the capacity review phase deepens the culture of knowledge use among independent self-motivated protégés. The culture of knowledge use effectively promotes collaborative participation through functional top-down and democratic bottom-up communication. This study recognises limitations of the naturalistic inquiry.

The research employed a limited sample of 31 respondents and this raises concerns over the transferability of findings. However, the use of questionnaires among 52 respondents provided a comprehensive understanding and knowledge of the problem. The study, though focusing on five local municipalities, can be viewed as unique despite possible considerable differences from other local municipalities. Interviews were held on 03 August 2016 just a few days before the local government elections. In the context of local government elections, the political environment is unfavourably filled with uncertainties (Mphahlele \& Zandamela, 2021). It is a period pregnant with uncertainties in relation to positions of senior management employed on contracts linked to the five-year contracts of the political office bearers.

\subsection{Conclusion: Towards Administrative Collaboration, Systemic Capacity Building and Socio-Political Resilience}

The research findings advance the belief that a learning environment underpins capacity development-oriented service delivery as an enabler for the overcoming of the perceived bureaucratic lacuna. This is consistent with capacity development as a learning process to achieve developmental goals (Otto et al., 2009). Additionally, institutions act as enablers of learning through human capital development (Taylor, 2007). It is therefore the firm argument of this study that a new organisational learning trajectory is possible to redress impediments against capacity development-oriented service delivery structures and programmes. 


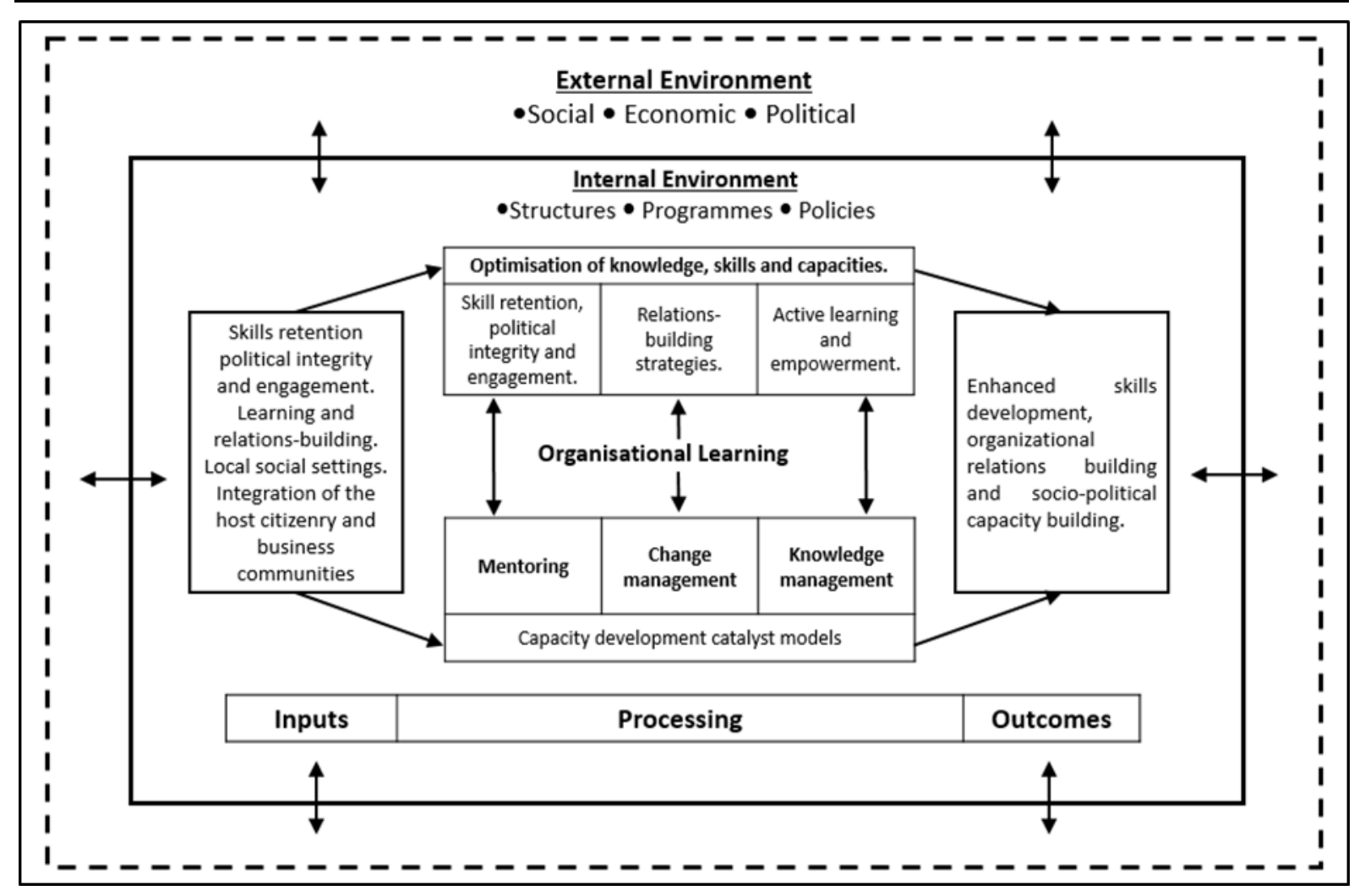

Figure 4. Capacity development oriented organisational learning theory

Source: Mphahlele (2021)

The study also identifies the thematic orientations that contribute to the existing body of knowledge. The emergent theoretical orientation, in Figure 4, is a revised version of the capacity development-oriented learning theory originally advanced by Mphahlele and Zandamela (2021) and premised on aspects associated with the problem of administrative collaboration, political integrity, and engagement. The new theoretical inclination and contribution to the existing body of knowledge affirms the promotion of participation and integration of the municipal officials, citizenry and business communities in all developmental programmes against the problem of a heterogeneous mobile population,

In the context of local government, organisational learning is inclusive of mentoring, knowledge management, and change management strategic gears or capacity development catalysts for optimising service delivery. The new theoretical implications and contribution to the existing body of knowledge underscore learning and, to some extent, relationship-building initiatives. This is in the context of managing the 'distance' between stakeholders.

Operational conclusions explained below address the question; "how does the attainment of functional and effective skills development outcomes facilitate developmental goals under transformative leadership?" 


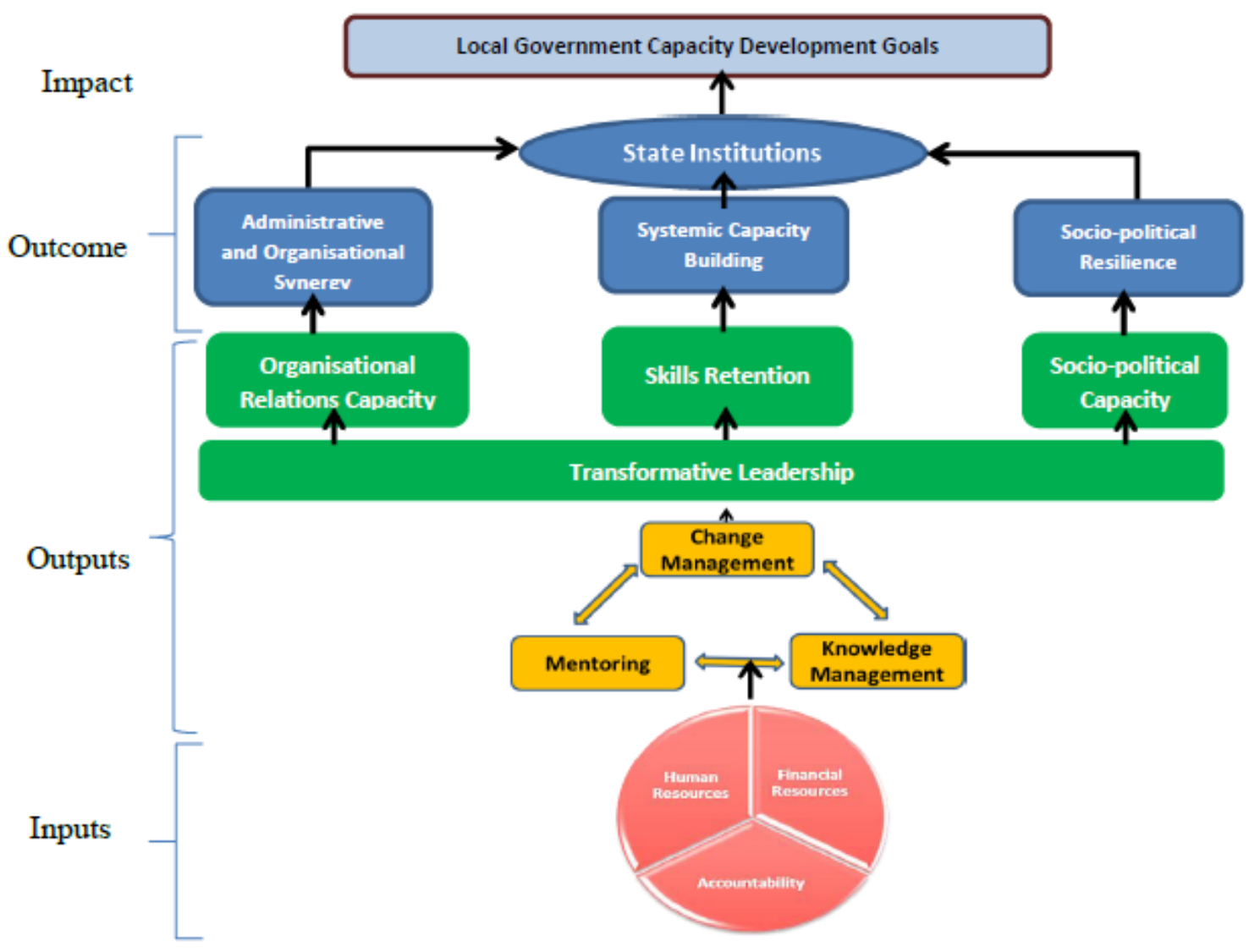

Figure 5. Local Government Capacity Development Framework

Source: Adapted from UNDP (2009)

Operational conclusions reveal that internal organisational levers, that is, accountability, and human and financial resources are in essence major inputs in the creation of a solid foundation for capacity development, as Figure 5 illustrates. The non-linear process of the optimisation of outcomes of capacity development commences with the integration of an input-oriented public accountability. This study proposes an integration of distinct elements of mentoring, knowledge and change management strategies. These strategies are indicative of operational gears essential to the efficient generation of outputs. Outputs in the form of organisational relations, skills retention and socio-political capacity significantly advance the outcomes, that is, functional administrative synergy, systemic capacity building programmes and collaborative socio-political resilience, respectively. These outcomes are key enablers of sustainable local government capacity development goals. 


\section{MInstitute Macrothink $^{\text {Int }}$}

Current studies and thinking in relation to the capacity development of service delivery initiatives focus on disjointed and generic advances that inadequately explain how disablers could be overcome. Premised on the intricacies of organisational relations, ineffective operational structures and programmes in relation to how disablers could be overcome, this study defines capacity development as the effective optimisation of service delivery enablers, and collective ownership of transformational developmental socio-economic programmes within a responsive and accountable political environment. A general pattern among senior managers is that the closer they are to political principals the more difficult the relationships as mistrust by the communities alienates municipal administrators from society as explained below.

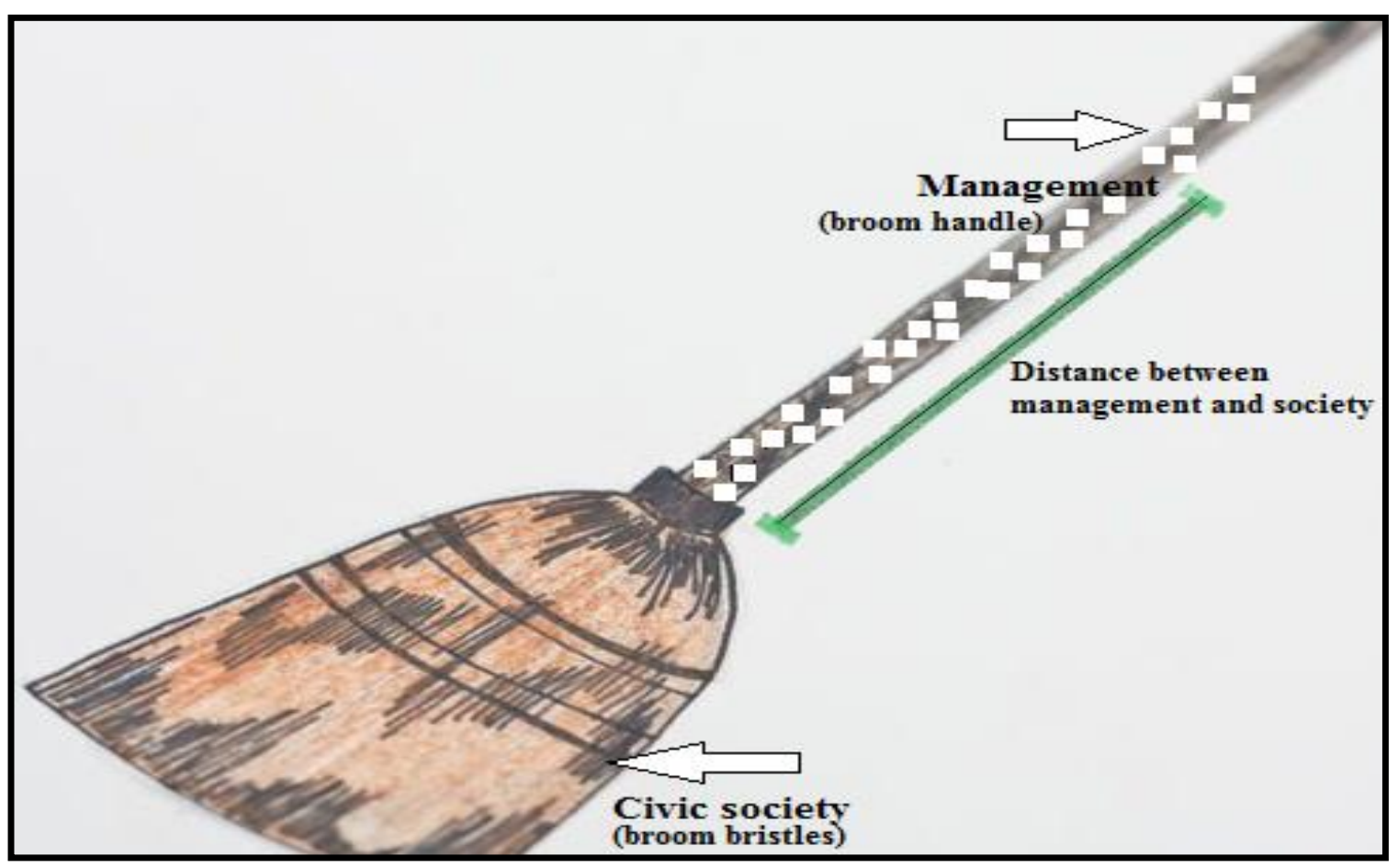

Figure 6. Management by Broomstick framework

Source: Mphahlele (2021).

Based on the uniqueness and intricacies of the relations and ineffective operational structures prominent in the findings, this study has developed a 'management by broom-stick' (MbB) framework. The framework in Figure 6 illustrates the phenomenon of poor management seen in the distance between the municipal council and communities. Figuratively, the distance between the handle of the broomstick (administration) and the broom bristles (communities) determines how effective the broom (municipality) functions. The longer the broomstick the further away the handle is from the bristles. It would also be difficult to effectively move the broom on the floor. As such, by implication, if knowledge workers or managers are far from communities it would be difficult to plan with them and listen to their needs. On the other hand, if the handle is too close to the broom bristles, one would be too close to the ground. This would make it difficult to move the broom, and one could even fall over. Thus, if management were too close to the communities, they could be susceptible to being 
manipulated by unscrupulous influential leaders running corrupt activities. One could also be biased and get captivated by trivial political and organisational dynamics on the ground. The question of how to manage a long enough distance between management and civil society is a negotiable and consensus-seeking polycentric and multi-stakeholder driven process.

This study addressed an existing knowledge gap by demonstrating the strategic link between capacity development and service delivery underpinned by systemic capacity building, socio-political resilience, and an administrative and organisational synergy that have a bearing on effective local government structures, programmes, and institutions. Although the original assumption was that capacity development contributes to optimising service delivery, the research findings indicate that organisational learning and skills development play important roles in enhancing the capacity development of service delivery structures and programmes.

In conclusion:

1. Administrative synergy and systemic capacity building could be supported by a municipal unit with research capability for the continuous upholding of ethics. The system should detect early warning signs of corruption, manage risks, heighten co-ordinating capacity development initiatives and consequence management for inadequate performance.

2. This paper argued that the maximisation of socio-political resilience against perceived political abandonment and dislocated councillors could be enhanced by strengthening organisational administrative collaboration and socio-political integrity. On-going monitoring and evaluation of service delivery structures and programmes should deepen the sustainability of socio-political resilience.

3. The challenges of collaborative organisational synergy and partnership in the 'Madibeng-Nyandeni corridor' could be overcome through organic or functional relationships and collaboration between the Bojanala and OR Tambo districts to alleviate the ensuing brain drain and inequality. Thus, the existence of a functional political will between the respective District Councils could narrow the distance or strengthen collaborative relations between the respective senior managers and councillors.

It is against the backdrop of the (1) peculiarly high mining labour influx, (2) de facto government roles of mining companies, (3) the Marikana tragedy typical of labour related inequalities, that the impact of the lack of capacity development and socio-economic inequality manifests into social-ills in the Bojanala Platinum District Municipality. Moreover, the laissez faire organisational culture is inflicted with party political activism and is fraught with win-lose contestations for high stakes in the 'low lying fruits' within the extractive capital economy at the expense of societal empowerment and service delivery. The study, therefore, recommends the creation of supportive monitoring and evaluation systems to advance the strengthening of functional hybrid governance structures and an organic communication model within a transparent and accountable administrative-political 
environment.

In the context and strength of findings in this research study, the following future studies are suggested: (1) the effectiveness of provincial government oversight for enhancing capacity development in local municipalities; (2) the significance of the implementation of service delivery mentoring programmes in the BPDM; (3) strategic reorientation of the Performance Management System consistent with local municipality service delivery programmes; and (4) the translation of change management strategies as mediating instruments for effective local government capacity development programmes.

\section{Acknowledgments}

The authors express sincere gratitude to municipal managers, senior managers and employees of the Bojanala Platinum District Municipality and the local municipalities that participated in this study. The project did not get any financial support. Dr. Matuku Mphahlele extends deepest appreciation to his supervisor Dr. Horacio Zandamela for the preparation of this paper as a variant of his $\mathrm{PhD}$ studies in Mphahlele (2021) and the subsequent paper, Mphahlele and Zandamela (2021).

\section{References}

Abdul-Korah, G. B. (2011). Now if you have only sons you are dead: Migration, Gender and Family Economy in Twentieth Century Northwestern Ghana. Journal of Asian and African Studies, 18(4), 390-403. https://doi.org/10.1177/0021909611400016

Adaawen, S. A., \& Owusu, B. (2013). North-South Migration and Remittances in Ghana. African Review of Economics and Finance, 5(1), 29-45. https://www.ajol.info/index.php/ aref/issue/view/11183

Akinboade, O. A., Mokwena, M. P., \& Kinfack, E. C. (2014). Protesting for Improved Public Service Delivery in South Africa's Sedibeng. District Social Indicators Research, 119(1), 1-23. https://doi.org/10.1007/s11205-013-0377-9

Allers, M. A., \& de Greef, J. A. (2018). Inter-municipal co-operation, public spending and service levels. Local Government Studies, 44(1), 127-150. https://doi.org/10.1080/03003 930.2017. 1380630

Amoako, E. E., \& Apusigah, A. A. (2013). Gender, Migration and Remittances in Ghana An Overview. Ghana Journal of Development Studies, $10(1 \quad \& \quad 2)$, 15-43. https://doi.org/10.4314/gjds. v10I1\&2.2

Ansell, C., \& Gash, A. (2007). Collaborative governance in theory and practice. Journal of Public Administration Research and Theory, 18(4), 543-571. https://doi:10.1093/jopart /mum032

Auditor-General. (2018). Consolidated general report on the audit outcomes of Local Government 2016-2017. Government Printers.

Badenhorst, C. (2007). Research Writing: Breaking the Barriers. Van Schaik Publishers 
Bebbington, A., Bornschlegl, T., \& Johnson, A. (2013). Political Economies of Extractive Industry: From Documenting Complexity to Informing Current Debates. Development and Change, 00, 1-16. https://doi.10.1111/dech.12057

Becker, G. S. (1993). Human Capital: A theoretical: A theoretical and empirical analysis with special reference to education. The University of Chicago Press.

Biggs, H., Mohamed, S., Wang, X., Colquhoun, S., \& Dovan, N. (2015). Challenges for the FIFO/DIDO Workforce: Impacts on Health, Safety and Relationships Industry Report September 2015. http://sbenrc.com.au/app/uploads/2014/09/P2.32_I ndustryReport_WEB.pdf

Blaeschke, F., \& Haug, P. (2018). Does inter-municipal cooperation increase efficiency? A conditional meta-frontier approach for the Hessian wastewater sector. Local Government Studies, 44(1), 151-171. https://doi.org/10.1080/03003930.2017.1395741

Bojanala Platinum District Municipality. (2016). Bojanala Annual Report 2014-2015. http://www.bojanala.gov.za/janala.boja/wp-content/uploads2016/05/BPDM-Annual-Report-2 014 -15.pdf

Bowles, S., \& Gintis, H. (1975). The Problem with Human Capital Theory-A Marxian Critique. The American Economic Review, 65(2), 74-82. http://www.jstor.org/stable/1818836

Busse, M., \& Gröning, S. (2013). The resource curse revisited: Governance and Natural Resources. Public Choice, 154, 1-20. https://doi.org/10.1007/s11127-011-9804-0

Carrington, K., \& Hogg, R. (2011). Benefits and Burdens of the Mining Boom for Rural Communities. Human Rights Defender. University of New South Wales

Carrington, K., Hogg, R., \& McIntosh, A. (2011). The resource boom's underbelly: Criminological impacts of mining development. Australian \& New Zealand Journal of Criminology, 44(3), 335-354. https://journals.sagepub.com/doi/10.1177/0004865811419068

Conde, M., \& Le Billion, P. (2017). Why do some communities resist mining projects while others do not? The Extractive Industries and Society, 4(3), 681-697. https: //doi.org/10.1016/ j. exis. 2017.04.009

Cooke, B., \& Kothari, U. (2001). Participation: The New Tyranny? Zed Books

Constitution of South Africa Act, No. 108 of 1996 (SA). https://www.justice.gov.za/legislation /constitution/SAConstitution-web-eng-0.pdf

Deming, W. E. (1982). Out of the crisis. MIT Press.

Denison, E. F. (1967). Why growth rates differ. The Brookings Institute.

Denzin, N. K., \& Lincoln, Y. S. (2011). Introduction: The discipline and practice of qualitative research. The Sage handbook of qualitative research. Sage.

Department of Mineral Resources. (2015). Mining Charter Impact Assessment Report. http://www.dmr.gov.za/publications/.../262-mining-charter-assessment-report-2015.html 
Dubihlela, J., \& Volschenk, A. B. (2017). Corporate Social Responsibility Intervention of one Mining Operator: A Community Development Case in Bojanala District, South Africa. International Business and Economics Research Journal, 16(1), 1-16. https://doi.org/10.19030/ iber. v16i1.9881

Dzansi, L.W., Chipunza, C., \& Monnapula-Mapesela, M. (2016). Municipal Employees' Perceptions of Political Interference in Human Resource Management Practices: Evidence from the Free State Province in South Africa. International Business and Economics Research Journal, 15(1), 15-26. https://doi.org/ 10.19030/iber.v15i1.9572

Edelenbos, J. (2005). Governance. An International Journal of Policy, Administration, and Institutions, 18(1), 111-134. https://doi.org/10.1111/j.1468-0491.2004.00268.x

Engineering Council of South Africa (2014). National Engineering Skills Survey. https://www.ecsa.co.za/news/Surveys\%20PDFs/200215_ECSA_National_Engineering_Skills _Survey_Report_April_2014.pdf

Fairhurst, D. (2007). Don't lose them, schmooze them. Human Resources, 10(2), 21-35. https://0-search.proquest.com.innopac.wits.ac.za/ docview/228294607?accountid=15083

Field, P. A., \& Morse, J. M. (1985). Qualitative Nursing research: The application of qualitative approaches. Aspen.

Fox, W., \& Meyer, I. H. (1995). Policies for public service transformation. Creda Press.

Employment Equity Act, No 55 of 1998 (SA). Retrieved from https://www.labour.gov.za /DocumentCenter/Acts/Employment\%20Equity/Act\%20-\%20Employment\%20Equity\%2019 98.pdf

Germà, B., \& Gradus, R. (2018). Privatisation, contracting-out and inter-municipal cooperation: new developments in local public service delivery. Local Government Studies, 44(1), 11-21. https://doi.org/10.1080/ 03003930.2017.1403904

Gilbert, T. F. (1978). Human Competence: Engineering worthy performance. McGraw-Hill.

Gordon, P. A. (2000). The road to success with mentor. Journal of Vascular Nursing, 18(1), 30-33. https://doi.org/10.1016/S1062-0303(00)90059-1.

Govender, P. (2014, March/April). Madibeng: Place of Water. South African Human Rights Commission. http://www.sahrc.org.za/ home/ index.php?ipkArticleID=257

Guba, E. G. (1981). Criteria for Assessing the Trustworthiness of Naturalistic Inquiries. Educational Communication and Technology, 29(2), 75-91. http://www.jstor.org/stable/ 30 219811

Guillermo, P., Burki, S. J., \& Dillinger, W. (1999). Beyond the Center: Decentralizing the State. World Bank.

Harbison, F. H., \& Myers, C. A. (1964). Education, Manpower and Economic Growth: Strategies of Human Resource Development. McGraw-Hill. 
Hinojosa, L. (2013). Change in rural livelihoods in the Andes: do extractive industries make any difference? Community Development Journal, 48(3), 421-436. https://doi.org/10.1093/cdj/ bst023

Hodder, R. (2009). Political interference in the Philippine civil service. Environment and Planning C Government and Policy, 27(5), 766-782. https://doi.org/10.1068/c0843b

Houghton, D. S. (1993). Long-distance commuting: A new approach to mining in Australia. The Geographical Journal, 159(3), 281-290. https://www.jstor.org/stable/3451278? origin= crossref

Hoyos, S. C. (2019). Extractive industry revenues and the subnational resource curse: The case of the Peruvian Andes. The Extractive Industries and Society, 6(4), 1134-1142. https://doi.org/10.1016/j.exis. 2019.06 .001

Huang, W., \& Feeney, M. K. (2016). Citizen Participation in Local Government Decision Making: The Role of Manager Motivation. Review of Public Personnel Administration, 36(2), 188-209. https://doi.org/ 10.1177/0734371x15576410

Imperial, M. (2005). Using collaboration as a governance strategy; lessons from six watershed management programs. Administration and Society, 37(3), 281-320. https://doi:10.1177/ 0095399705276111

Kaur, P., Stoltzfus, J., \& Yellapu, V. (2018). Descriptive statistics. International Journal of Academic Medicine, 4(1), 60-63. https://doi.org10.4103/IJAM.IJAM_7_18

Keown, N. (2005). Digging deep for better health: A study of the health status of men in the Goldfields mining industry of Western Australia. Overview report. https://www.scribd.com/ document/95835117/ Digging-Deep-for-Better-Health

Kickert, W. J. M. (2014). The Specificity of Change Management in Public Organizations: Conditions for Successful Organizational Change in Dutch Ministerial Departments. The American Review of Administrative Science, 44(6), 693-717. https://doi.org/ 10.1177/0275 074013483871

Korten, D. C. (1995). When corporations rule the world. Berrett-Koehler Publishers.

Kotter, J. P. (1996). Leading Change. Harvard Business School Press.

Kwankye, S. O. (2012). Independent North-South Child Migration as a Parental Investment in Northern Ghana. Population, Space and Place, 18(5), 535-550. https://doi.org/:10.1002/psp. 682

Labonne, B. (2002). Commentary: Harnessing mining for poverty reduction, especially in Africa. Natural Resources Forum, 26, 69-73. https: //doi.org/10.1111/1477-8947.00007

Lewin, K. (1947). Frontiers of Group Dynamics: Concept, method and reality in social science, social equilibria, and social change. Human Relations., 1(1), 5-41. https://doi.org/10.1177/001872674700100103 
Likert, R. (1932). A Technique for the measurement of attitudes. Archives of Psychology, 22(140), 5-55. https://www.researchgate.net/publication/ 200086112_ A_ Technique_for_ Measurement_of_Attitudes.

Local Government Handbook. (2016). Bojanala Platinum District Municipality. http://www.localgovernment.co.za/districts/view/9/Bojanala-Platinum-District-Municipality\# map

Local Government Municipal Systems Act, No. 32 of 2000 (SA). Retrieved from https://www.gov.za/sites/default/files/gcis_document/201409/a32-000.pdf

Local Government: Municipal Structures Act, No. 117 of 1998 (SA). Retrieved from https://www.gov.za/sites/default/files/gcis_document/201409/a117-980.pdf

Lohnert, B., \& Steinbrink, M. (2005). Rural and Urban Livelihoods: A Translocal Perspective in A South African Context. South African Geographical Journal, 87(2), 95-103. https://doi.org/10.1080/03736245.2005.9713832.

Lust, J. (2014). Social Struggle and the Political Economy of Natural Resource Extraction in Peru. Critical Sociology, 42(2), 195-210. https://journals.sagepub.com/doi/10.1177/ 0896920 513501354

Madibeng Local Municipality. (2015). Madibeng Local Municipality IDP Review 2014/15. http://www.madibeng.gov.za/wp-content/ uploads/2015/07/ idpreview_201415.zip

Mansuri, G., \& Rao, V. (2004). Community-Based and Driven Development: A Critical Review. World Bank Research Observer, 19(1), 1-39. http://hdl.handle.net/ 10986/14310

March, J. G., \& Olsen, J. P. (1989). Rediscovering Institutions. The Organizational Basis of Politics. Free Press.

Mayer, P., \& Mayer, I. (1971). Townsmen or Tribesmen. Conservatism and the Process of Urbanisation in a South African City. Oxford University Press.

McAdam, R., \& McCreedy, S. (1999). The Process of Knowledge Management within Organizations: A Critical Assessment of both Theory and Practice. Knowledge and Process Management, $6(2)$, 101-113. https://doi.org/10.1002/(sici)1099-1441(199906)6:2<101::aid-kpm53>3.0.co;2-p

Merriam, S. B. (2002). Qualitative research in practice. Jossey-Bass.

Mineral and Petroleum Resources Development Act, No. 28 of 2002 (SA). Retrieved from https://www.gov.za/sites/default/files/gcis_document/201409/a28-020.pdf

Mining Qualifications Authority. (2014). Sector Skills Plan for the Mining and Mineral Sector. https://mqa.org.za/mqa-sector-skills-plan/

Morse, J. M. (1991). Approaches to qualitative-quantitative methodological triangulation. Nursing Research, 40(2), 120-123. https://www.ncbi.nlm. nih.gov/ubmed /2003072

Mphahlele, M. (2021). Capacity Development of Service Delivery Structures and 
Programmes in Bojanala Platinum District Municipality. Unpublished Doctoral Dissertation. University of Witwatersrand.

Mphahlele, M., \& Zandamela, H. (2021). Local Government Capacity Development: A Case Study of a South African District Municipality. Journal of Public Administration and Governance, 11(2), 156-177. https://doi.org/10.5296/jpag.v12i1

Municipal Finance Management Act, No. 56 of 2003 (SA). https://www.gov.za/sites/default/files/gcis_document/201409/a56-03.pdf

Muswaka, L. (2014). Thematic Lessons from the Marikana Miners' Strike in South Africa: A Corporate Governance Perspective. Mediterranean Journal of Social Sciences, 5(2), 63-67. https://doi.org/10.5901/ mjss.2014.v5n2p63

National Planning Commission. (2011). National Development Plan: Vision 2030, Pretoria, South Africa. https://www.nationalplanningcommission.org.za/ National_Development Plan

National Treasury. (2011). Local government budgets and expenditure review. Department of Finance

Ndebele, C., \& Lavhelani, P. N. (2017). Local Government and Quality Service Delivery: An Evaluation of Municipal Service Delivery in a Local Municipality in Limpopo Province, Journal of Public Administration, 52(2), 340-356. https://hdl.handle.net/10520/EJC -bf4ce318a

Nealer, E. (2014). Local government and service delivery. In Gerrit van der Walt (Ed.), Municipal Management: Serving the people (Chapter 9), 2nd ed. JUTA.

Ngwenya, P., \& Botha, P. (2014). The foster care backlog: A threat to the retention of social workers? Social Work, 48(20), 209-224. https://doi.org/10.15270/48-2-99.

Nygren, A. (2005). Community-based forest management within the context of institutional decentralization in Honduras. World Development, 33(4), 639-655. https://doi:10.1016/j.worlddev.2004. 11.002

Organisation for Economic Co-operation and Development. (2008). The Challenge of Capacity Development: Working Towards Good Practice. Journal on Development, 8(3), 233-276. https://doi.org /10.1787/journal_dev-v8-art40-en

Osei-Kojo, A., \& Andrews, N. A. (2020). developmental paradox? The "dark forces" against corporate social responsibility in Ghana's extractive industry. Environment, Development and Sustainability, 22(2), 1051-1071. https://doi.org/10.1007/s10668-018-0233-9

Otto, S., Agapitova, N., \& Behrens, J. (2009). The Capacity Development Results Framework: A strategic and results-oriented approach to learning for capacity development. World Bank.

Pegg, S. (2006). Mining and poverty reduction: transforming rhetoric into reality. Journal of Cleaning and Productivity, 14 (2006), 376-387. https://doi.org/10.1016/j.jclepro.2004.06.006

Platteau, J. (2008). Participatory Governance and the Millennium Development Goals. UN 


\section{Macrothink}

Journal of Public Administration and Governance ISSN 2161-7104 2022, Vol. 12, No. 1

Rocco, T.S., \& Plakhotnik, M.S. (2009). Literature Reviews, Conceptual Frameworks, and Theoretical Frameworks: Terms, Functions, and Distinctions. Human Resource Development Review, 8(1), 120-130. https://doi:10.1177/1534484309332617

Roux., N.L., \& Nyamukachi, P.M. (2005). A reform model for the improvement of municipal service delivery in South Africa. Journal of Public Administration, 40(4), 687-705. http://hdl.handle.net/2263/3908

Rummler, G. A., \& Brache, A. P. (1988). The Systems View of Human Performance. Training, 25(9), 45-53. http://www.performancedesignlabcom/wp-content/uploads/2012/04/40.-The-Systems-View-o f-Human-Performance1.pdf

Sana, M., \& Massey, D. S. (2005). Household Composition, Family Migration, and Community Context: Migrant Remittances in Four Countries. Social Science Quarterly, 86(2), 509-528. https://doi.org/10. 1111/j.0038-4941.2005.00315.x

Satgar, V. (2012). Beyond Marikana: The Post-Apartheid State. Africa Spectrum, 47(2/3), 33-62. https://doi.org/10.1177/000203971204702-303

Serbeh, R., Adjei, P. O., \& Yeboah, T. (2015). Internal Migration and Poverty Reduction: Rethinking the Debate on the North-South Movement in Ghana. Journal of Social Sciences, 12(1), 42-54. https://doi.org/10.3844/jsssp.2015

Shava, E., \& Maramura, T. C. (2016). A Descriptive Analysis of the Causes, Challenges and Effects of Skills Deficit on Youth Empowerment in South Africa. Journal of Social Sciences, 49(1,2), 93-100. https://doi.org/10.10 80/09718923.2016.11893602

Skills Development Act, No. 98 of 1998 (SA). Retrieved from https://www.gov.za/sites/ default/files/gcis_document/201409/a97-98.pdf

Somville, V. (2006). Information Distortion in Community-Based Development, Working Paper, Center for Research on the Economics of Development (CRED): University of Namur

Soukopová, J., \& Vaceková, G. (2018). Internal factors of inter-municipal cooperation: What matters most and why? Local Government Studies, 44(1), 105-126. https://doi.org/10.1080/0300393 0.2017.1395739

South African Government (1994). President Nelson Mandela: 1994 State of the Nation Address. https://www.gov.za/state-nation-address-0

Sorensen, P. (2012). The Marikana Tragedy International Journal of Environmental Studies, 69(6), 871-873. https://doi.org/10.1080/00207233.2012.734046

Stark, O. (1991). The Migration of Labor. Basil Blackwell.

Stark, O., \& Lucas, R. E. B. (1988). Migration, Remittances, and the Family. Economic Development and Cultural Change, 36(3), 465-81. https://econpapers.repec.org /RePEc:ucp:ecdecc:v:36:y:1988:i:3:p:465-81 
Statistics South Africa. (2013). Census 2011. Government Printers.

Statistics South Africa. (2016). Community Survey. http://cs2016. statssa.gov.za/

Statistics South Africa. (2017). Poverty Trends in South Africa. An examination of absolute $\begin{array}{llll}\text { poverty } & \text { between } & 2006 & \text { and }\end{array}$ https://www.statssa.gov.za/publications/Report-03-10-06/Report-03-10-062015.pdf

Steinbrink, M. (2010). The Role of Amateur Football in Circular Migration Systems in South Africa. Africa Spectrum, 45(2), 35-60. https://d-nb.info /1024414043/34

Swanson, R. A. (1999). The foundation of performance improvement and implications for practice. Berret-Koehler

Taylor, L. (2007). Knowledge, information and the business process: Revolutionary thinking or common sense? Chandos Publishing Limited

Tembo, F. (2003). Participation, Negotiation and Poverty: Encountering the Power of Images. Ashgate

Turrel, R. (1986). Diamonds and Migrant Labour in South Africa, 1869-1910. History Today, 36(5), 45-49. http://0-web.b.ebscohost.com.innopac.wits. ac.za/ehost/

Van der Voet, J., Kuipers, B. S., \& Groeneveld, S. (2016). Implementing Change in Public Organizations: The relationship between leadership and affective commitment to change in a public sector context. Public Management Review, 18(6), 842-865. https://doi.org/10.1080/14719037.2015.1045020

Waheduzzaman., \& Mphande, C. H. B. (2012). Gaps in Pursuing Participatory Good. Governance: Bangladesh. Administration and Society, 46(1), 37-69. https://doi.org/10.1177\% 2F0095399712451891

Wilson, S. A. (2013). Company-Community Conflicts Over Diamond Resources in Kono District, Sierra Leone. Society and Natural Resources, 26(3), 254-269. https://doi.org/10.1080/ 08941920.2012.684849

Wolpe, H. (1972). Capitalism and cheap labour power in South Africa: From segregation to apartheid. Economy and Society, 1(4), 425-456. https://doi.org/10.1080/03085147200000023

Zula, K. J., \& Chermack, T. J. (2007). Human Capital Planning: A review of literature and implications for Human Resource Development. Human Resource Development Review, 6(3), 245-262. https://doi. org/10.1177/1534484307303762

\section{Copyright Disclaimer}

Copyright for this article is retained by the author(s), with first publication rights granted to the journal.

This is an open-access article distributed under the terms and conditions of the Creative Commons Attribution license (http://creativecommons.org/licenses/by/4.0/). 